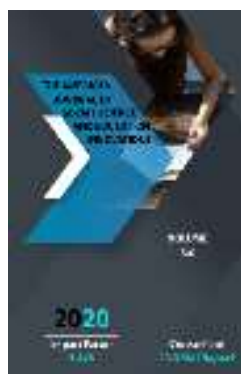

\title{
Methods And Tools For Making Student 'S Creative Activity In Elementary Technology Classes
}

\author{
Uralova Muhabbat Sanjar Qizi \\ Teacher Of Elementary Classes At School Number 1, Uzbekistan
}

Journal Website:

http://usajournalshub.c om/index,php/tajssei

Copyright: Original content from this work may be used under the terms of the creative commons attributes 4.0 licence.

\section{ABSTRACT}

In elementary classes using creative activities is the most vital part of the lesson. They learn everything easily by creativity. In technology classes of elementary level learners it can help their creative skills and impression. In addition to this, teacher should enhance their creativity during the lesson. To improve these kinds of skills instructor should apply different methods and tools. In this article, methods and tools of improving learners creativity are stressed.

\section{KEYWORDS}

Creativity, technology classes, develop, learner, activity, enhance, tools, creative, ideas, original, process, toolbox, skill, improve, method, satisfying, various.

\section{INTRODUCTION}

First of all, creativity itself means the use of imagination or original ideas to create something; inventiveness. It is a phenomenon whereby something somehow new and somehow valuable is formed. The created item may be intangible such as an idea, a scientific theory, a musical composition, or a joke or a physical object such as an invention, a printed literary work, or a painting. Scholars advise using the application of creative resources to improve the effectiveness of teaching and learning. As we look it in etimology the English word creativity comes from the Latin term creare, "to create, make": its derivational suffixes also come from Latin. The word "create" appeared in English as early as the 14th 
century, notably in Chaucer, to indicate divine creation

However, its modern meaning as an act of human creation did not emerge until after the Enlightenment. In a summary of scientific research into creativity, Michael Mumford suggested: "Over the course of the last decade, however, we seem to have reached a general agreement that creativity involves the production of novel, useful products" or, in Robert Sternberg's words, the production of "something original and worthwhile".

Promoting intrinsic motivation and problem solving are two areas where educators can foster creativity in students. Students are more creative when they see a task as intrinsically motivating, valued for its own sake. To promote creative thinking, educators need to identify what motivates their students and structure teaching around it. Providing students with a choice of activities to complete allows them to become more intrinsically motivated and therefore creative in completing the tasks. Using creative activities may help to increase the learner's outlook and horizon. Step by step instructor should teach the students or pupils to use the creative skills during the classes. If learner's creativeness do not shape, teacher should exclude them in pupil 's mind. It is also useful for the learners to improving the skills of creativity in elementary classes of technology.

Creativity is like a muscle. It must be stretched, challenged, and occasionally pushed past its comfort zone. It can be flourished with the help of various methods and here I will try some of them:

\section{To Learn Through Collaboration}

Curiosity will lead the learner to creativity.

Andrew Ng, formerly of Google and now of Baidu, is one who doesn't believe innovation is due to unpredictable flashes of genius. Rather, he said you can become more creative and innovative systematically. "In my own life, I found that whenever I wasn't sure what to do next, I would go and learn a lot, read a lot, talk to experts. I don't know how the human brain works but it's almost magical: when you read enough or talk to enough experts, when you have enough inputs, new ideas start appearing."

Indeed, collaborating with and learning from others may be just what the pupils need to give their creativity a boost. Therefore the teacher should create such kind of atmosphere that pupils are able to work and learn through collaboration with counterparts.

\section{To help to do something they love}

In a letter to his son, Albert Einstein provided a great bit of fatherly insight when addressing his son's interest in playing the piano that is applicable to losing yourself in the creative process: do something that pleases you.

"That is the way to learn the most, that when you are doing something with such enjoyment that you don't notice that the time passes," Einstein wrote. "I am sometimes so wrapped up in my work that I forget about the noon meal."

Love and creativity are intertwined. A hobby, such as playing an instrument, running, or collecting memorabilia, can help your pupil relax and fight stress while giving their creativity a boost. Thus, you should help your learner find the things or works that they love and train with them.

\section{Change The Surroundings}

Changing the surroundings can effect the mind of the learner. For example, you may add temporary shades or strip old wallpaper in the class and replace it with a new pattern; adjust the lighting and change the settings in classroom, from dimly lit to illuminated or vice versa, and you will see it has an instant effect on learner' and also your mood. 
Redecorating pupil's environment not only provides them with a new perspective on their studying space, it also provides their creative self with a new angle on their project or idea. This method can play a significant role of improving the creativeness of the learner. Every teacher may apply their own lesson and they can compare the result to the previous one.

\section{Stop Criticizing The Learner}

You can't be both creative and critical. The latter limits the former by blocking your and your learner's ability to recognize that even the ideas that seem like bad ones can be polished and used in the future. Never be harsh on your pupils. Understand that everything is a process and that they are creative no matter what they are struggling with at the moment. Criticizing the learner's may destroy the belief in themselves, also they may lost all creative skills. So, stop criticizing the pupils as much as you can. It can help you everywhere to achieve good results.

\section{Experiment: Be creative and teach creatively in other ways.}

Don't limit yourself and your learners during technology classes. Fatigue is one barrier to creativity that pupils can avoid simply by taking breaks, or focusing on something else for short periods of time. You and also your pupils can be creative in other ways; you can use your creativity to pursue pupil's other interests. The best thing about expanding their creative bubble is that you have an opportunity to practice your and their creativity in novel ways, even within the same sphere.

\section{DO SOME PHYSICAL ACTIVITY}

Research from some scholars, has shown that by 'letting the learners go' through exercise can allow them to boost their creativity. Walking and running were seen to expose participants to an array of different environmental cues that stimulated the brains imagination and thus creativity. During the outdoor classes it can be possible and it will be enjoyable and interesting by this student's creativity may increase.

\section{FIND THEIR HAPPY PLACE}

When you find your pupil's happy place, they can find an ideal setting to be more creative in. A study investigating the effect of mood states on creativity found that when people were in a positive mood, they became more creative. People who were in a positive mood thought dynamically to solve a variety of different problems.

However, people who were in a bad mood were less creative and inevitably solved less problems. A positive attitude provides an insight into situations you wouldn't necessarily think of when in a negative mood, promoting a more creative way of thinking.

All in all, creativity is the key of creating great things. In technology classes, it is needed all time. Developing the learners creative skills is somehow difficult but with the help of useful tips, methods and tools it can be done in an easy way and the lesson will be successful. Teacher may expand your students' creativity toolbox by exploring and teaching some of these tools. Effective creativity tasks consider pupils' content knowledge, use convergent but emphasize divergent thinking, incorporate creative thinking strategies, engage students in tasks that have meaning for them, and provide informational feedback so that students under- stand their progress. It will be helpful in all time. Creativity is considered as the crucial part of everything. So, teacher should pay great attention to these skills of the learners.

\section{REFERENCES}


1. Mumford, M. D. (2003). "Where have we been, where are we going? Taking stock in creativity research". Creativity Research Journal. 15 (2-3): 107-120.

2. Sternberg, Robert J. (2011). "Creativity". Cognitive Psychology (6 ed.). Cengage Learning. p. 479

3. "More On Idea Generation Tools and Techniques. Idea Flow: Discussion about innovation and creativity - new products, strategy, open innovation, commercialization of technologies..." Archived from the original on 2014-02-24. Retrieved 2007-06-20.

4. "Idea Generation, Creativity and Incentives" (PDF). Mitsloan.mit.edu. Archived from the original (PDF) on 201305-20. Retrieved 2013-08-25.

5. "Group creativity techniques to collect requirements". projectmanagement.com. 13 July 2012

6. Black, R. (1990a). But we can't allow 25 different answers to the same question in our classrooms

7. https://blog.innerdrive.co.uk/8-ways-toimprove-creativity 